ENSAIO BIBLIOGRÁFICO

\title{
TRÊS PERSPECTIVAS SOBRE A POLÍTICA EXTERNA DOS ESTADOS UNIDOS: PODER, DOMINAÇÃO E HEGEMONIA ${ }^{1}$
}

\author{
Alexsandro Eugenio Pereira
}

\begin{abstract}
RESUMO
Nos estudos sobre o poder americano, um aspecto parece fundamental: a construção da liderança dos Estados Unidos, que se expressa, dentre outras formas, por meio da criação e manutenção de instituições internacionais capazes de estabelecer um ambiente favorável ao exercício desse poder nas relações internacionais do século XX. Para compreender esse aspecto o uso do conceito de hegemonia é essencial. Nesse sentido, o presente ensaio tem como propósito examinar três interpretações distintas sobre a política externa dos Estados Unidos e verificar como utilizaram esse conceito em suas análises. As interpretações foram elaboradas por Joseph Nye Jr. e Immanuel Wallerstein, nos Estados Unidos, e por Cristina Soreanu Pecequilo, no Brasil. Especificamente, o ensaio pretende mostrar: (i) como interpretam o poder americano e (ii) como utilizam o termo "hegemonia" para explicar esse poder no século XX. As três análises refletem perspectivas teóricas distintas a partir das quais o poder americano é examinado. Elas inscrevem-se, também, na significativa produção bibliográfica recente a respeito do comportamento e das estratégias internacionais dos Estados Unidos e suas implicações para a política internacional contemporânea.
\end{abstract}

PALAVRAS-CHAVE: Estados Unidos; politica externa; poder; hegemonia; dominação.

\section{INTRODUÇÃO}

Após o final da primeira década do século XXI, o debate sobre o declínio do poder americano é um dos mais recorrentes da literatura recente das relações internacionais. Esse debate persiste devido à significativa importância da posição internacional dos Estados Unidos nos séculos XX e XXI. Diversos temas abordados na atualidade dependem dessa posição: o encaminhamento de temas transnacionais, como os direitos humanos, o meio ambiente, as migrações internacionais, o terrorismo, entre outros. Uma das questões centrais da atual conjuntura depende do comportamento e dos interesses internacionais da superpotência restante: a discussão e o avanço de projetos de reforma dos principais regimes e instituições internacionais com o propósito de readequá-los à complexidade da política mundial contemporânea. Afinal, a contribuição americana foi decisiva para a consolidação e o desempenho dos papéis desses regi-

\footnotetext{
1 Agradeço os comentários valiosos e as recomendações dos pareceristas anônimos da Revista de Sociologia e Politica, que contribuíram para a versão final deste ensaio bi-
} bliográfico. mes e instituições. Uma eventual reconfiguração de poder dentro do Conselho de Segurança², por exemplo, avançaria se houvesse a adesão dos Estados Unidos a qualquer uma das propostas que contemplam maior participação de potências regionais importantes como a Alemanha, a Índia e o Brasil.

A importância dos Estados Unidos torna relevante a literatura que trata de sua política externa. No meio acadêmico, proliferam livros e artigos abordando essa política nos séculos XX e XXI. Dentro dessa produção incontável ${ }^{3}$, destaca-se a necessidade de entender o desenvolvimento do poder americano no século XX com o objetivo de situá-lo na política internacional do período posterior à Guerra Fria. Nesse sentido, as interpretações sobre o poder americano são variadas e re-

\footnotetext{
2 No Conselho de Segurança da Organização das Nações Unidas (ONU), cinco membros permanentes (Estados Unidos, França, Reino Unido, Rússia e China) desfrutam de uma condição privilegiada e desigual em relação aos membros não permanentes, podendo fazer uso do poder de veto às decisões tomadas dentro do Conselho.

3 São exemplos dessa produção: Vizentini e Wiesebron (2006), Jervis (2005), Fiori (2007), entre outros.
} 
fletem as dificuldades experimentadas pelo desenvolvimento teórico das relações internacionais, pois tratar do poder americano significa abordar uma das principais questões teóricas do estudo das relações internacionais: como se exerce o poder em um ambiente caracterizado pela anarquia - compreendida como a ausência de um governo mundial capaz de disciplinar a conduta dos estados e de outros atores não estatais. Essa questão é tratada pelas diferentes perspectivas teóricas que abordam os fenômenos internacionais e não é exclusividade das teorias realistas, mais centradas no exercício do poder. Podemos observar preocupação semelhante na vertente liberal dos anos 1970, que desenvolveu uma análise particular sobre o poder no contexto do que essa vertente chamou de "interdependência complexa".

Para compreender o exercício do poder nas relações internacionais, diferentes teóricos procuraram caracterizar as especificidades do ambiente no qual ele é exercido. Eles reconheceram a inexistência de um governo mundial, mas divergiram sobre a natureza do ambiente no qual os estados interagem. Termos como "poder", "dominação" e "hegemonia" aparecem, com frequência, no vocabulário dos analistas e possuem sentidos diferentes, pois estão atrelados às suas perspectivas teóricas. Os diferentes entendimentos sobre esses termos terão reflexo, conseqüentemente, nas análises sobre o poder americano. A título de exemplo, podemos examinar o conceito de hegemonia e a forma pela qual ele aparece em análises fundamentadas em perspectivas teóricas distintas das relações internacionais como o realismo, o liberalismo e o marxismo. A aplicação desse conceito nos estudos de relações internacionais mostrouse fundamental, pois permitiu explicar o status de poder específico desfrutado por determinados estados, denominados de hegemônicos. No entanto, podemos identificar o uso do termo hegemonia nas relações internacionais com sentidos distintos nas três perspectivas teóricas mencionadas acima.

O uso do termo hegemonia, no entanto, é fundamental para compreender-se o poder americano e o debate sobre seu eventual declínio. É fundamental, pois, no sentido gramsciano, "hegemonia" envolve a capacidade de liderança de uma fração de classe em relação às demais frações. Aplicado às relações internacionais, a hegemonia envolve a capacidade de liderança de um Estado em relação aos demais. Neste sentido preciso, falar em declínio do poder americano envolveria discutir as dificuldades enfrentadas pelos Estados Unidos para legitimar suas intervenções militares e exercer, de maneira efetiva, seu papel de liderança no mundo atual.

Evidentemente, é preciso reconhecer que o exercício do poder nas relações internacionais do século XX difere substancialmente das condições nas quais a Grã-Bretanha, por exemplo, impôs seu domínio na cena internacional do século XIX. As relações internacionais do século XX envolvem uma multiplicidade maior de atores estatais e o desenvolvimento expressivo dos não estatais, cujo reflexo aparece na atualidade com o debate a respeito da formação ou não de uma sociedade civil global. O desenvolvimento desses atores não estatais fez com que os Estados Unidos produzissem uma modalidade particular de império (um império de funções e não de território), conforme apontou Raymond Aron (apud VILLA, 1999, p. 57). As empresas multinacionais americanas preencheriam o papel dos exércitos na medida em que realizaram uma forma de dominação econômica similar ao dos impérios europeus, mas sem o recurso à anexação de territórios e populações. Além disso, os Estados Unidos construíram, ao lado da Europa ocidental e do Japão, uma ordem internacional baseada em instituições econômicas e políticas cuja operação dependeu da sua capacidade de liderar e formar um consenso mínimo no sistema internacional. $\mathrm{O}$ recurso ao conceito de hegemonia gramsciano novamente é fundamental para explicar essa ordem e sua importância nas relações internacionais do século $\mathrm{XX}$, por formar-se fundamentada no consenso, não no recurso à força. Sem entrar no velho debate sobre a eficácia ou não das instituições internacionais, é necessário reconhecer a existência e a variedade dessas instituições e de seus papéis na cena internacional do século passado e do mundo posterior à Guerra Fria.

Nesse sentido, a novidade do poder americano não estaria no aumento progressivo e exponencial de um dos seus principais fundamentos: a capacidade bélica. Neste quesito, os Estados Unidos reproduziram um padrão de comportamento similar ao das grandes potências do pas$\mathrm{sado}^{4}$. É interessante observar, como fez Pecequilo (2005), que suas relações externas foram condi${ }^{4}$ A esse respeito, ver Braudel (1987); Kennedy (1989);
Tilly (1996); Fiori (2007), entre outros. 
cionadas por interesses constituídos no seio de sua sociedade, entre os quais os interesses de seus setores produtivos. A dimensão econômica condiciona o poder americano e interfere no comportamento internacional dos Estados Unidos. No entanto, chama a atenção um aspecto importante: a forma pela qual os Estados Unidos construíram sua liderança, expressa, dentre outras maneiras, por meio da criação e manutenção de instituições internacionais capazes de estabelecer um ambiente favorável ao exercício desse poder nas relações internacionais do século XX. Para compreender essa novidade é necessário recorrer ao conceito de hegemonia.

Nessa direção, o presente ensaio verificará como três interpretações sobre o poder americano abordaram esse aspecto. Com este propósito, o ensaio examinará três livros publicados no início do século XXI. Dois destes foram escritos por analistas filiados a perspectivas teóricas distintas das relações internacionais: o neoliberal Joseph Nye Jr. e o marxista Immanuel Wallerstein. O terceiro livro foi escrito pela brasileira Cristina Soreanu Pecequilo, que realizou uma análise histórica da política externa dos Estados Unidos. Tomando-os como referência, o ensaio mostrará, de maneira específica: (i) como interpretam o poder americano e (ii) como utilizam o termo hegemonia para explicar esse poder no século XX.

Para realizar esses propósitos, o ensaio estrutura-se em três partes. A primeira examina, de maneira sumária, o conceito de hegemonia e sua aplicação nos estudos de relações internacionais a partir das perspectivas de Robert Cox, de Giovanni Arrighi e da Teoria da Estabilidade Hegemônica. A segunda estabelece um contraponto entre as três perspectivas, mostrando como explicam o poder americano. A terceira examina como os três autores aplicam o conceito de hegemonia para explicar o poder americano. Nas considerações finais, o ensaio apontará como as três perspectivas posicionam-se no debate sobre o eventual declínio desse poder no século XXI.

\section{O CONCEITO DE HEGEMONIAE SUAAPLI- CAÇÃO NOS ESTUDOS DE RELAÇÕES IN- TERNACIONAIS}

No campo das relações internacionais, o conceito de hegemonia vem sendo utilizado em pelo menos três perspectivas diferentes, a saber: a de Robert Gilpin e Charles Kindleberger, que elaboraram a Teoria da Estabilidade Hegemônica nos anos 1970; as Teorias do Sistema-Mundo de Immanuel Wallerstein e a dos ciclos hegemônicos de Giovanni Arrighi; e as contribuições recentes dos chamados neogramscianos, como Robert Cox e Stephen Gill. As duas primeiras integram a chamada Economia Política Internacional e estabelecem a relação entre hegemonia e expansão da economia capitalista a partir de uma perspectiva histórica. A aplicação do conceito de hegemonia pelos neogramscianos contribuiu para explicar as transformações na ordem mundial recente. O uso do conceito gramsciano de hegemonia não é exclusividade dos teóricos das relações internacionais inscritos no campo do marxismo, como se pode perceber pela análise das contribuições de Robert Gilpin e Charles Kindleberger ou mesmo dos autores neoliberais institucionalistas, como Robert Keohane. Nesta seção, o propósito é examinar, de maneira sumária, o significado do termo hegemonia e suas aplicações nos estudos de relações internacionais. Nela, abordarei as contribuições dos neogramscianos, de G. Arrighi e dos teóricos da estabilidade hegemônica. $\mathrm{O}$ conceito de hegemonia na Teoria do Sistema-Mundo de Wallerstein será tratado na terceira seção deste ensaio.

Segundo Robert Cox (1986), o termo hegemonia é empregado nas relações internacionais em dois sentidos, um mais restrito e outro mais abrangente. No sentido restrito, "hegemonia" significa a dominação de um Estado ou um conjunto de estados sobre os demais. Segundo Cox, o discurso realista reduziu hegemonia à dimensão de dominância: ela envolveria a relação entre as capacidades físicas dos diferentes estados. O sentido mais abrangente aproxima-se do conceito formulado por Antônio Gramsci. Segundo Martin Carnoy (1990), Gramsci compreende a hegemonia como o processo pelo qual a fração de classe dominante exerce liderança moral e intelectual na sociedade civil e baseia essa liderança no consenso junto às demais frações burguesas e às classes dominadas (cf. CARNOY, 1990, p. 95).

Essa dimensão do conceito é relevante para pensar-se as relações entre os estados, embora não seja essa a aplicação do conceito de hegemonia idealizada pelo filósofo italiano. O conceito de hegemonia de Gramsci remonta as leituras realizadas por ele de duas perspectivas: a de I. I. Lênin e a de N. Maquiavel. A segunda é a mais interessante. Gramsci e Maquiavel consideram que a questão geral envolvida na hegemonia é a nature- 
za do poder. O poder seria um centauro, meio homem, meio animal, uma combinação de "força" e "consciência" (COX, 1986).

Apesar de empregar o termo hegemonia para explicar as formações sociais capitalistas, Gramsci forneceu indicações sobre uma eventual aplicação desse termo à compreensão das relações internacionais. Ele indaga-se: "As relações internacionais precedem ou seguem (logicamente) as relações sociais fundamentais? Sem dúvida que seguem" (GRAMSCI, 1978, p. 188; sem grifos no original). As relações internacionais seriam importantes na medida em que interferem sobre as relações políticas no plano interno de um país. Para Gramsci, "quanto mais a vida econômica imediata de uma nação está subordinada às relações internacionais, tanto mais um determinado partido representa esta situação e a explora para impedir o predomínio dos partidos adversários [...]" (ibidem). Robert Cox (2007) toma a primeira passagem como referência para pensar a aplicação do conceito de hegemonia às relações internacionais. Nesse sentido, é necessário frisar que essa aplicação é tarefa empreendida pelos chamados neogramscianos, entre os quais o próprio Cox e Stephen Gill.

Robert Cox sustenta que a aplicação do conceito gramsciano implica localizar historicamente períodos nos quais houve efetivamente o estabelecimento de uma hegemonia nas relações internacionais. Ele estabelece quatro períodos: 1845$1875 ; 1875-1945 ; 1945-1965 ; 1965$ até o presente (no caso, o ano de 1983, quando seu trabalho é publicado pela primeira vez). Esse último período seria caracterizado pela crise da ordem mundial conduzida pelos Estados Unidos ${ }^{5}$.

Para tornar-se hegemônico, um Estado precisaria preencher algumas condições mencionadas pelo autor. A primeira delas envolve a criação, por parte de um Estado, de uma ordem mundial reco-

\footnotetext{
5 A partir da crise da ordem mundial, Cox identifica três cenários possíveis de "transformação estrutural da ordem mundial", a saber: "a reconstrução da hegemonia com a ampliação de uma gerência política de acordo com as linhas propostas pela Comissão Trilateral; o aumento da fragmentação da economia mundial, que giraria em torno de esferas econômicas centradas em grandes potências; e a possível afirmação de uma contra-hegemonia baseada no Terceiro Mundo, precedida pela exigência de uma Nova Ordem Econômica Internacional (NOEI)" (COX, 2007, p. 117).
}

nhecida pelos demais estados como compatível com seus interesses. Essa ordem, no entanto, não seria concebida apenas no plano dos estados, mas envolveria as forças sociais do capitalismo que alcançariam condições de operar em escala mundial. A segunda condição estaria associada à primeira. Para Cox, o estabelecimento de uma hegemonia mundial é resultado de uma "expansão para o exterior" de uma hegemonia nacional estabelecida por uma classe dominante. "As instituições econômicas e sociais, a cultura e a tecnologia associadas a essa hegemonia nacional tornam-se modelos a serem imitados no exterior" (idem, p. 118). Por meio dessa expansão, é formada uma ordem mundial baseada na hegemonia de um Estado sobre os demais. A terceira condição é a expansão da hegemonia para os países periféricos, que incorporam alguns aspectos econômicos e culturais do "núcleo hegemônico" sem, no entanto, alterar, de modo significativo, seus regimes políticos. Por essa razão, o modo de produção capitalista expande-se para os países periféricos sem que, internamente, esses países modifiquem de modo substantivo as antigas estruturas de poder vigentes. Por isso, é possível observar, nesses países, regimes autoritários orientados para o desenvolvimento capitalista. A manutenção dessas estruturas de poder tem reflexos no desenvolvimento da hegemonia, que é mais intensa e coerente entre os países centrais e mais contraditória na periferia.

Em síntese, Cox situa a hegemonia na cena internacional como o estabelecimento de uma ordem conduzida por um Estado hegemônico no seio de um modo de produção dominante e expansivo. A hegemonia não envolve apenas os estados, mas também as classes sociais dominantes em cada um deles. A hegemonia mundial definir-se-ia, segundo o autor, como a combinação de três estruturas: a social, a econômica e a política. "Além disso [prossegue o autor], a hegemonia mundial se expressa em normas, instituições e mecanismos universais que estabelecem regras gerais de comportamento para os estados e para as forças da sociedade civil que atuam além das fronteiras nacionais - regras que apoiam o modo de produção dominante" (idem, p. 119). As instituições e regras internacionais seriam mecanismos da hegemonia. Em outros termos, elas não apenas facilitam a expansão das forças econômicas e sociais dominantes, mas produzem ajustamentos necessários com o propósito de gerar concessões 
aos interesses subordinados dos países periféricos com custos reduzidos. É importante destacar que as concessões das classes ou estados dominantes às classes ou estados subordinados são necessárias para a continuidade da hegemonia. Nesse sentido, as instituições e regras internacionais são fundamentais.

Ao mesmo tempo, Cox destaca que elas desempenham importante papel ideológico na medida em que expressam idéias, valores e crenças fornecidas pelas forças sociais e econômicas dominantes. As instituições internacionais são capazes, também, de cooptar as elites dos países periféricos e seduzir indivíduos interessados em transformar o modo de produção. Esses indivíduos são provenientes dos países periféricos e optam por trabalhar nessas instituições com o propósito de modificar o status quo dominante. No entanto, possuem baixa capacidade de realizar seu propósito, pois as instituições absorvem "idéias potencialmente contra hegemônicas" para torná-las consistentes com a doutrina do Estado hegemônico. Para exemplificar essa situação, Cox trata da noção de autossuficiência, mostrando que ela, inicialmente, procurava contestar a economia mundial, defendendo a premissa de que os países periféricos deveriam buscar um desenvolvimento econômico independente e "endogenamente determinado". Transformada pelas instituições internacionais, essa premissa foi convertida em programas de capacitação das populações dos países periféricos com o propósito de fazer com que elas gerassem, por conta própria, seus meios de subsistência. Dessa forma, a autossuficiência foi adequada aos objetivos da economia mundial, transferindo para essas populações a responsabilidade de buscar uma integração às benesses econômicas do capitalismo.

Em outro artigo, Cox (1986) afirma que as instituições providenciam modos de lidar com o conflito e minimizar o uso da força nas relações internacionais. Dessa forma, o exercício de poder estaria baseado no consentimento e, em menor grau, no uso da coerção (força). A força pode ser usada para os fortes solaparem os fracos. Porém, a força não será necessária para o domínio dos mais fortes se os fracos aceitarem a legitimidade da liderança. Nas relações internacionais, haverá sempre um equilíbrio tênue na relação entre o líder e seus liderados. O líder necessita reafirmar, a todo instante, que sua condição é necessária e atende o interesse geral. Essa é a forma pela qual a liderança torna-se possível, pois, ao manifestar que age de acordo com seus interesses particulares, o líder não conseguirá obter o consentimento dos liderados.

Diferentemente de Cox, Arrighi (2007) concentra-se mais nas relações entre os estados recorrendo, também, ao conceito gramsciano de hegemonia. Assim como Cox, Arrighi também está interessado em estabelecer historicamente o que ele denominou de "as hegemonias do capitalismo histórico", que seriam três: a holandesa, a britânica e a norte-americana. No entanto, ao tratar do conceito de hegemonia mundial, Arrighi sugere que ele refere-se a um poder exercido por um Estado com o propósito de desempenhar "funções governamentais sobre um sistema de estados soberanos" (cf. ARRIGHI, 2007, p. 227; sem grifos no original). Esse poder seria mais do que dominação: seria o exercício de uma "liderança moral e intelectual" nos termos de Antônio Gramsci (1978, p. 228). A hegemonia envolveria a noção de poder formulada por Maquiavel e compartilhada por Gramsci, conforme foi apontado em um parágrafo precedente desta seção do ensaio. Essa noção envolve coerção ("força") e consentimento ("consciência"). No que diz respeito à consciência, envolve a capacidade de um grupo dominante (nas formações sociais capitalistas) ou de um Estado (nas relações internacionais) apresentar-se como representante do interesse geral do conjunto dos estados nas relações internacionais. Para realizar essa condição, o Estado precisa construir o consenso em torno de interesses gerais compartilhados pelos demais estados. Trata-se, portanto, do exercício da liderança de que falava Gramsci. Mas, para Gramsci, dominar não teria o mesmo significado de liderar (cf. GARCIA, 2010, p. 162). Para exercer a liderança, a fração de classe dominante precisaria fazer concessões aos grupos subordinados para, dessa forma, $o b$ ter a adesão desses grupos ao seu projeto de dominação. "A hegemonia pressupõe, portanto, levar em consideração os interesses e tendências dos grupos sobre os quais a hegemonia deve ser exercida. Isso significa que o grupo dominante terá que fazer certos sacrifícios de tipo econômico-corporativo, desde que não toquem no essencial de seu poder econômico" (Gramsci apud GARCIA, 2010, p. 162).

Com preocupações diferentes dos neogramscianos e de Arrighi, a teoria da estabilidade hegemônica emprega, também, o conceito de 
hegemonia articulado com a construção de uma ordem econômica liberal. Essa teoria pode ser inscrita no realismo e na Economia Política Internacional. Segundo Gilpin (2002, p. 85-138), a potência hegemônica (ou hegemon) consegue e deseja estabelecer normas e regras de uma ordem econômica liberal baseada nos preceitos do livremercado e da não discriminação. A teoria sustenta que um tipo particular de ordem econômica liberal não pode desenvolver-se sem um poder hegemônico. Para que essa ordem funcione é necessário o compromisso da potência hegemônica com o liberalismo. Sem esse compromisso, a conseqüência seria a formação de um sistema imperial baseado na imposição de restrições políticas e econômicas às potências menores. Além disso, é preciso que outros estados poderosos compartilhem interesses comuns associados à ampliação das relações de mercado. Dessa forma, três requisitos são essenciais para o estabelecimento de um sistema internacional de mercado liberal: hegemonia, ideologia liberal e interesses comuns (idem, p. 93).

Segundo Gilpin, os estados mais poderosos submetem-se à liderança por causa do prestígio e do status do hegemon no sistema político internacional. Para que essa liderança seja alcançada, no entanto, é fundamental um grau considerável de consenso ideológico ou "hegemonia ideológica". Nesse ponto, Gilpin afirma que a teoria da estabilidade hegemônica utiliza o conceito gramsciano de hegemonia, mostrando que a teoria sustenta a necessidade de uma liderança amparada não apenas na força, mas, também, no consenso ideológico gerado pelo hegemon. Por essa razão, o Estado que exerce a liderança precisa apresentá-la como benéfica e favorável aos demais estados, pois se eles perceberem que a potência hegemônica toma decisões em proveito próprio e contrárias aos interesses políticos e econômicos desses estados, o sistema ficará debilitado. Ao mesmo tempo, a potência hegemônica pondera sobre os custos e vantagens da liderança: se os custos forem maiores do que as vantagens obtidas com ela, a hegemonia entra, também, em declínio. Para a teoria da estabilidade hegemônica, só existiram dois momentos históricos nos quais se estabeleceu uma liderança conduzida por um hegemon: no século XIX até a I Guerra Mundial, exercida pela Grã-Bretanha; e pelos Estados Unidos depois da II Guerra Mundial, com a criação do General Agreement on Tariffs and Trade (GATT) e do
Fundo Monetário Internacional (FMI), entre outras instituições econômicas internacionais. Durante esses momentos, houve uma expansão do mercado internacional e da interdependência econômica global (idem, p. 93).

Ao mesmo tempo, a expansão e o dinamismo da potência hegemônica estimulam o crescimento do sistema econômico internacional, na medida em que suas importações promovem o crescimento das outras economias e seus investimentos fornecem, aos países em desenvolvimento, o financiamento necessário ao crescimento econômico. A potência hegemônica transfere, também, tecnologia e conhecimento para as economias subdesenvolvidas com o propósito de alavancar o desenvolvimento industrial e econômico dessas economias. E, por fim, o hegemon seria responsável pelo fornecimento de bens públicos globais (a moeda internacional estável, a economia de mercado e o sistema de segurança coletiva seriam exemplos desses bens) dos quais todos os países usufruem. As tarefas desempenhadas pela potência hegemônica no processo global de crescimento asseguram a manutenção do sistema: quando o crescimento global declina, o sistema entra em crise (idem, p. 96). Concretamente, essa situação pôde ser observada nos anos 1970, quando se inicia, segundo a teoria formulada por Kindleberger e Gilpin, o declínio da hegemonia americana.

Nos anos 1980, segundo Cox (1986), Robert Keohane tentou ampliar a perspectiva realista ao retomar a teoria da estabilidade hegemônica e ao mostrar as variações que podem ocorrer na autoridade das normas internacionais e das instituições de acordo com a presença de um hegemon. O declínio do hegemon pode acarretar a diminuição da observância das normas da ordem internacional. Robert Keohane (2005) examinou as possibilidades de cooperação entre os estados em um contexto de discussão da crise da hegemonia americana. A questão fundamental para Keohane era entender de que forma os regimes internacionais poderiam funcionar na ausência de uma potência hegemônica garantidora desses regimes. O argumento de After Hegemony, livro publicado por Keohane em 1984 (idem), sustenta que a cooperação pode realizar-se sem hegemonia, o que implica considerar que ela não requer, necessariamente, a participação americana (idem, p. XII). A possibilidade da cooperação global sem os Estados Unidos resulta das diferenças crescentes de valores entre a Europa (e alguns democracias in- 
dustriais) e a América. Cada lado pensa em questões como a regulação estatal da economia, a provisão de benefícios da prosperidade e o respeito à lei internacional de maneiras diferentes. Por isso, a substância das regras nas novas instituições criadas será diferente sem os Estados Unidos do que seria com a participação efetiva e integral dos americanos (idem, p. XIII) $)^{6}$.

A teoria crítica de Robert Cox e a teoria da estabilidade hegemônica analisam a liderança exercida pela potência hegemônica de maneiras distintas. Cox mostra, por exemplo, que a hegemonia mundial envolve a combinação das estruturas sociais, políticas e econômicas, conforme foi apontado anteriormente. A teoria da estabilidade hegemônica ressalta a importância da liderança política e ideológica do hegemon cujo propósito é assegurar a ordem econômica liberal. Para essa teoria, em dois momentos históricos foi possível observar a presença de uma liderança dessa natureza. A teoria crítica de Cox, no entanto, ressalta um número maior de períodos nos quais foi possível identificar a presença de uma potência hegemônica. A diferença entre as duas teorias reside na forma como elas compreendem a dinâmica do capitalismo. Robert Cox destaca o papel das forças sociais nessa dinâmica. Gilpin, por sua vez, enfatiza a importância decisiva da liderança política e ideológica de um único Estado capaz de gerar a prosperidade no contexto de uma ordem econômica liberal.

Desse conjunto de considerações teóricas, considero pertinente reter dois pontos principais: (i) a aplicação do conceito de hegemonia tem-se mostrado fundamental para compreender o papel desempenhado por determinados estados na cena internacional. Em uma perspectiva liberal como a de Keohane, esse papel estaria associado à operação de instituições internacionais cuja função seria viabilizar a cooperação entre os estados. Em uma perspectiva realista e inscrita dentro da Economia Política Internacional, como é o caso de Robert Gilpin, a potência hegemônica é fundamental para a estabilidade da ordem econômica baseada no liberalismo. Na perspectiva marxista de

6 No livro, Keohane faz uma discussão sumária sobre o conceito de hegemonia em diferentes perspectivas teóricas. Ver, a esse respeito, Keohane (2005, p. 31-46), capítulo três, intitulado "Hegemony in the World Political Economy".
Wallerstein e Arrighi, a hegemonia permite examinar os ciclos de desenvolvimento da economiamundo capitalista. Retomarei a utilização do conceito de hegemonia na perspectiva de Wallerstein na seção III deste ensaio, bem como as diferenças entre as perspectivas de Wallerstein e Arrighi; (ii) a análise do poder por meio do conceito de hegemonia formulado por Gramsci. Baseado em Maquiavel, Gramsci sugeriu a necessidade de pensar o conceito por meio da combinação de coerção e consciência. Pensar o poder americano significa examiná-lo a partir dessa dupla conceitual, já que ele não pode ser compreendido apenas à luz do uso da força. Na sequência, o ensaio tentará mostrar como os três autores abordados interpretam o poder americano e como empregam conceitos distintos de hegemonia para explicá-lo.

\section{O PODER AMERICANO SEGUNDO JOSEPH \\ NYE JR., IMMANUEL WALLERSTEIN E CRISTINA SOREANU PECEQUILO}

Os três autores aqui examinados produziram interpretações sobre o poder americano informadas por perspectivas teóricas distintas. Por isso, suas interpretações destacam elementos distintos do poder americano. Em Nye Jr., a análise é construída com base em uma descrição sobre os fundamentos desse poder, contextualizados em um cenário de globalização e revolução da informação. Nye Jr. parte de uma definição do que seria o poder, entendido como "a capacidade de obter resultados desejados e, se necessário, mudar o comportamento dos outros para obtê-los" (NYE JR., 2002a, p. 30). Essa capacidade, por sua vez, dependeria dos fundamentos do poder nas relações internacionais: $(i)$ os fundamentos militares e econômicos que formarão o chamado hard power ou poder bruto; (ii) a capacidade de moldar a vontade dos demais estados por intermédio da "atração exercida pela cultura e pela ideologia" (idem, p. 38, nota 31), que seria o soft power ou poder brando. Wallerstein analisa o poder americano no contexto de desenvolvimento do sistemamundo, termo utilizado pelo autor para explicar o sistema internacional a partir da integração de suas dimensões políticas e econômicas. Essas dimensões, por sua vez, estariam integradas pela lógica da acumulação capitalista que determinaria o papel desempenhado pelos estados no sistema-mundo. Partindo dessa orientação teórica, Wallerstein considera que os Estados Unidos seriam a última hegemonia do sistema-mundo, tendo em vista $o$ 
papel desempenhado por esse país no desenvolvimento do capitalismo nas últimas décadas.

Pecequilo, por sua vez, não se filia a qualquer uma das teorias dos dois autores. Sua análise pode ser situada no quadro de uma leitura histórica da política externa dos Estados Unidos a partir da qual a autora sustentou a tese de que essa política seria marcada por continuidades e mudanças. No desenvolvimento de sua análise, ela identificou um padrão histórico que começou a constituir-se no momento da formação dos Estados Unidos como nação. Para a autora, apesar dos ajustes e adaptações necessárias no curso da história, a política externa americana preservou elementos desse padrão. Esses elementos servem de explicação para as opções estratégicas adotadas pelos americanos a partir do momento em que se tornaram uma nação independente e, mais tarde, passaram a ter importância crucial para as relações internacionais nos séculos XX e XXI.

Nas três análises, é possível identificar as particularidades do poder americano. A análise de Pecequilo concentra-se nos elementos propriamente políticos e procura mostrar como eles articular-se-iam, também, com preocupações de natureza econômica. Wallerstein, ao contrário, concentra-se na condição hegemônica dos Estados Unidos no contexto da economia-mundo capitalista. Concentra-se, portanto, nos elementos econômicos capazes de orientar a conduta externa da superpotência. Nye Jr., por sua vez, enfatiza a importância da dimensão não econômica e militar do poder americano, especialmente a partir dos anos 1970. Ele examina a dimensão econômica por meio da análise da globalização e da revolução da informação, destacando o papel preponderante desempenhado pelos Estados Unidos nessa dimensão. Nye Jr. não identifica, também, rivais capazes de competir abertamente com os Estados Unidos e concentra-se em mostrar de que forma esse país tenderia a continuar dominante se não comprometer sua capacidade de moldar o comportamento dos outros estados por meio do exercício do poder brando. Em síntese, as três análises recuperam particularidades importantes da conduta externa dos Estados Unidos. Essas particularidades são relevantes para compreender-se o exercício do poder americano.

No seu estudo, Pecequilo observou que os princípios determinantes da conduta externa dos Estados Unidos foram constituídos no momento da formação da nação americana, a partir do seu primeiro ato, que foi a Revolução Americana e a Declaração de Independência de 1776. Os Estados Unidos tornaram-se uma nação independente lutando contra as restrições impostas pela GrãBretanha, buscando autonomia e liberdade para determinar sua forma de governo e perseguir seus interesses comerciais. A Declaração de Independência expressa os valores fundamentais sustentados pela nação americana: todos os homens e nações devem ser criados livres e iguais, dotados de direitos inalienáveis à vida, à liberdade e à procura da felicidade (cf. PECEQUILO, 2005, p. 37). O nascer livre, de acordo com J. G. Ruggie (apud PECEQUILO, 2005, p. 37) envolvia a idéia do isolamento e da proteção dos Estados Unidos por vastos oceanos, pela não proximidade de inimigos imediatos entre seus vizinhos, por sua autossuficiência interna e pela capacidade de expansão, ainda somente potenciais no século XVIII (idem).

Outra particularidade observada pela análise de Pecequilo (idem, p. 53) está relacionada ao segundo elemento do padrão histórico: o isolacionismo e o unilateralismo. Para compreender esses dois termos, a autora faz um esclarecimento sobre cada um deles, pois não seriam sinônimos, mas complementares. O isolacionismo é uma estratégia de engajamento na qual os Estados Unidos adotam uma posição menos destacada e comprometida no sistema internacional e evitam assumir responsabilidades e formar alianças permanentes com outros países. Já o unilateralismo é a conduta externa orientada para manter e ampliar a total e completa liberdade de ação do país (o oposto do unilateralismo seria o multilateralismo). No momento em que esses dois conceitos integraram o padrão histórico da política externa, os Estados Unidos desejavam afastarse das disputas de poder que se processavam na Europa, tentando manter a qualquer custo a liberdade de ação externa do país.

Para Wallerstein, o desenvolvimento do poder americano esteve associado, em grande medida, ao funcionamento da economia-mundo capitalista cujo ciclo de vida é marcado por sua gênese, pelo seu desenvolvimento normal e, no presente, por um período de crise terminal. Logo, a crise mais abrangente do sistema comprometeria a hegemonia norte-americana. Ele recupera o período histórico no qual essa hegemonia começou a construir-se ainda no século XIX, com o pro- 
gressivo enfraquecimento econômico britânico. Nesse século, Alemanha e Estados Unidos iniciaram uma competição pela "sucessão hegemônica". Ambos expandiram sua base industrial e ultrapassaram a Grã-Bretanha no período de 1870 a 1914. Nesse sentido, Wallerstein entende que as duas guerras mundiais seriam, na verdade, uma única e contínua guerra entre alemães e americanos para determinar a próxima hegemonia do sistema-mundo. Os alemães teriam cometido um equívoco na ascensão do Nazismo ao tentar transcender o sistema por meio da formação de um império global com a anexação de territórios.

Os Estados Unidos venceram o confronto com a Alemanha e buscaram substituir a Grã-Bretanha por meio do estabelecimento de uma nova hegemonia. Terminado o longo período de guerra, os Estados Unidos envolveram-se nos esforços de reconstrução da Europa ocidental. Após 1945, emergiram como a única grande potência industrial do mundo que saiu incólume dos conflitos. Seu principal problema era a ausência de demanda efetiva, com poucos compradores no mundo devido ao declínio do poder de compra na Europa ocidental e no Leste da Ásia. Portanto, era necessário reconstruir. Para atender a essa necessidade, o governo americano precisava resolver um problema político: a significativa oposição interna aos dispêndios de recursos econômicos necessários à reconstrução européia. Não bastava acenar com a possibilidade de converter o auxílio em demanda efetiva dos produtos americanos. Era preciso encontrar uma justificativa aceitável para aqueles dispêndios. $\mathrm{O}$ argumento encontrado para vencer a resistência interna e aprovar o Plano Marshall no Congresso americano foi a contenção do comunismo. Para isso, o governo americano "torceu" para que a União Soviética não aderisse ao Plano Marshall - de qualquer forma, os Estados Unidos não teriam recursos suficientes para atender toda a Europa (incluindo o Leste) arrasada pelo conflito mundial.

Os Acordos de Yalta ${ }^{7}$, celebrados pelas potências vitoriosas ao final da II Guerra Mundial, fo-

7 Foram acordos assinados pelos chefes de Estado das principais potências aliadas na II Guerra Mundial em 11 de fevereiro de 1945: Franklin Delano Roosevelt, pelos Estados Unidos; Winston Churchill, pelo Reino Unido e Josef Stalin, pela União Soviética. Para uma análise do sistema de Yalta e de suas implicações para o Terceiro Mundo, cf. Vizentini (1997). ram funcionais para os interesses econômicos norte-americanos e confirmaram o statu quo favorável aos Estados Unidos. Cada um dos países vitoriosos da guerra permaneceria com os "territórios" conquistados no campo de batalha. Em outras palavras, coube à União das Repúblicas Socialistas Soviéticas (URSS) um terço do mundo e aos Estados Unidos o restante. Em certa medida, os Acordos de Yalta podem ser interpretados como forma de estabelecer os limites de atuação das duas superpotências no mundo. Esses acordos seriam, também, uma estratégia de contenção da URSS, o que teria possibilitado o estabelecimento de uma geopolítica favorável à expansão econômica liderada pelos Estados Unidos a partir de 1945. Para Wallerstein, o período de 1945 a 1967-1973 foi o momento alto da hegemonia americana no sistema-mundo capitalista, no qual ocorreu a maior expansão de toda a história desse sistema, tanto de valor como de produção real, criando enorme riqueza e, ao mesmo tempo, grande tensão social. Para realizá-lo, os Estados Unidos precisavam, também, de uma ordem mundial relativamente estável, conseguida por meio da criação e da sustentação de um conjunto de instituições intergovernamentais (a Organização das Nações Unidas (ONU), o Fundo Monetário Internacional e o Banco Mundial). No lado americano, os Acordos de Yalta, a criação da Organização do Tratado do Atlântico Norte (OTAN) e o Tratado de Segurança Estados Unidos-Japão favoreceram uma geopolítica de segurança na qual ficou de fora o restante dos países, como todo o Terceiro Mundo, os grupos menos favorecidos do mundo ocidental e os estados do leste europeu e central, submetidos, a contragosto, ao jugo soviético.

O exercício de poder pelos Estados Unidos fundamentou-se, portanto, em sua posição econômica privilegiada no sistema-mundo capitalista, exercendo o que seria a última hegemonia desse sistema mergulhado em uma crise sistêmica. Essa análise é informada por uma perspectiva que, do ponto de vista teórico, alimenta-se tanto do realismo como do marxismo. A teoria do sistema-mundo de Wallerstein privilegia os fatores econômicos que são determinantes do comportamento do Estado nas relações internacionais e inscreve-se na Economia Política Internacional de viés marxista.

Para explicar a crise sistêmica, o autor examina as três principais tendências geradoras dessa crise: $i$ ) A tendência ao aumento do nível salarial 
real como percentagem dos custos de produção, calculado em média na economia-mundo como um todo. Wallerstein observa que, para resolver os problemas da pressão dos trabalhadores por melhores salários, os capitalistas deslocam unidades de produção para locais nos quais a força política dos trabalhadores e os salários pagos sejam menores. Porém, o que está ocorrendo hoje é uma tendência à diminuição da oferta de mão-de-obra barata e o resultado líquido seria uma pressão maior sobre os níveis de lucro; ii) Aumento dos custos do tratamento das matérias-primas, exemplificado pelo tratamento de matérias-primas que geram a emissão de produtos tóxicos. Tais custos ambientais podem ser socializados ou podem ser internalizados. Quanto mais as empresas são obrigadas a arcar com esses custos, maiores pressões serão exercidas sobre a acumulação de capital. Porém, não seria justa a transferência do ônus à sociedade; iii) A elevação do nível de tributação devido à necessidade de satisfazer exigências populares. Atender a essas exigências é fundamental para manter uma relativa estabilidade política. Elas envolvem três variedades principais: instituições educacionais, instalações de saúde e garantias de rendimento ao longo da vida dos indivíduos (subsídios de desemprego e segurança social para os idosos) (cf. WALLERSTEIN, 2004, p. 71).

Como se pode notar, a análise de Wallerstein prioriza os elementos econômicos (o desenvolvimento da economia-mundo capitalista), situandoos como determinantes da conduta política externa dos Estados Unidos. A construção de instituições intergovernamentais após a II Guerra Mundial e os Acordos de Yalta estariam atrelados, nessa análise, a preocupações econômicas: a criação de uma ordem estável para a expansão econômica dos Estados Unidos. Em contraste, a análise de Pecequilo enfatiza os elementos políticos e tenta mostrar de que forma os EUA orientaram-se pela defesa de sua liberdade e autonomia frente a qualquer restrição imposta por outros países e até mesmo pelas instituições internacionais que ajudaram a fundar no século XX. Isso explicaria, por vezes, a posição contraditória dos Estados Unidos frente a essas instituições, como se pode observar na intervenção recente no Iraque em 2003. Do ponto de vista interno, a defesa da autonomia, da liberdade e da unidade nacional determinou a configuração dos mecanismos institucionais e o exercício do poder político. Dessa forma, o sistema político americano é "dominado pela sociedade" e é suscetível às pressões exercidas pelos cidadãos, pelos grupos organizados, pelas empresas e pelas organizações não governamentais, entre outros setores da sociedade. Em outros termos, isso possibilitou ao Estado americano lançar-se na busca pelo poder nas relações internacionais com propósitos econômicos, atendendo a necessidades de seus setores produtivos organizados no plano interno. Pecequilo constatou esse ponto ao observar que o esgotamento da capacidade do mercado interno americano de incorporar a produção levou os Estados Unidos a aumentar seu engajamento internacional ainda no século XIX. A política externa, portanto, orientou-se para a realização dos interesses comerciais, algo que persiste até os dias de hoje naquele elemento do padrão histórico apresentado pela autora e denominado de "política de portas abertas". Essa política persiste na expansão exponencial de acordos bilaterais dos Estados Unidos com parceiros comerciais em diversas partes do mundo nos anos 1990.

A fragilidade do Estado americano frente à sociedade civil foi observada, ainda, por S. Krasner e P. Katzenstein (citados em Cox (1986)). Os autores consideram que nos Estados Unidos o Estado é fraco em relação à força da sociedade civil (ou, mais particularmente, em relação aos interesses da sociedade civil) enquanto outros estados, como Japão ou França, seriam mais fortes em relação às suas sociedades. A sociedade civil é vista, no caso dos EUA, como limitadora da efetividade do Estado (idem), o que dá margem à possibilidade de uma leitura marxista a respeito das relações entre Estado e sociedade neste país. Ao mesmo tempo, essa leitura contribui para entender como a política externa americana é condicionada pelas determinações provenientes da sociedade civil.

Segundo Cox, o materialismo histórico foca o processo produtivo como elemento crítico na explicação da forma histórica particular assumida por um complexo Estado-sociedade. Nesse sentido, a produção de bens e serviços, criadora da riqueza da sociedade e base para a habilidade de um Estado mobilizar o poder por trás de sua política externa, ocorre por meio de um relacionamento de poder entre aqueles que controlam e aqueles que executam as tarefas da produção. Essa visão do materialismo histórico, expressa por Cox, corresponde à forma particular pela qual Wallerstein examinou o papel do poder político na economia-mundo capitalista. Tal visão, no entanto, mostra como a expansão do poder americano 
pode ser pensada em conformidade com as condições apontadas por Cox para um Estado tornarse hegemônico: os Estados Unidos constituíram uma hegemonia mundial e ela pode ser vista como resultado das necessidades de expansão internacional de suas forças sociais internas.

Dessa forma, é possível compreender os motivos pelos quais os Estados Unidos oscilam entre condutas externas paradoxais (como o unilateralismo e o multilateralismo) no curso de sua história. O paradoxo dessas condutas tem, na verdade, uma explicação: a primazia da liberdade, da autonomia e da sociedade civil sobre a formulação das estratégias internacionais adotadas pelo país. Esse paradoxo, no entanto, não é o mesmo observado por Joseph Nye Jr. (2002a). O paradoxo de Nye Jr. está relacionado às condições específicas nas quais se processa o exercício do poder americano na política mundial contemporânea. Essas condições explicariam as razões para a importância atribuída pelo autor ao chamado poder brando (soft power).

Para o autor, é tão importante a um país impor sua vontade por meio de sanções econômicas e armas militares como por meio de sua capacidade de estabelecer a agenda na política mundial utilizando, para esse fim, a cooptação e as possibilidades de atração dos outros países. O poder brando baseia-se na capacidade de definir a agenda política para formar a preferência dos demais. Mas, adverte o autor, o poder brando não é simplesmente sinônimo de influência, já que influência também pode ser exercida por intermédio de ameaças impostas pelo poder bruto. $\mathrm{O}$ poder brando define-se como "a capacidade de seduzir e atrair" que leva "à aquiescência e à imitação" (idem, p. 38, nota 31). Em outros termos, o poder brando é uma forma de exercício de poder baseada na persuasão, no convencimento e, mais importante ainda, na capacidade de atração. "Em resumo, a universalidade da cultura de um país e a capacidade de estabelecer um conjunto de normas e instituições favoráveis que governem setores de atividade internacional são fontes decisivas de poder. Os valores da democracia, da liberdade pessoal, da mobilidade social e da abertura, frequentemente expressos na cultura popular americana, a instrução superior e a política externa contribuem com o poder do nosso país em muitas áreas" (idem, p. 39).

Para compreender seu argumento, é preciso examinar as novas condições nas quais o poder é exercido na política mundial. Dentre essas condições, ele chama atenção para: $i$ ) a diminuição da importância da força militar no sistema internacional contemporâneo; ii) os impactos gerados pela revolução da informação e pela globalização sobre a autoridade e a soberania dos estados nacionais; iii) a emergência de novos atores que disputam poder com os estados nas relações internacionais ${ }^{8}$. Ao sugerir a redefinição do papel da força militar, Nye Jr. tenta sustentar que esse fundamento é importante, mas menos decisivo no exercício do poder na política internacional contemporânea. Ele já havia chamado a atenção para esse ponto em outros escritos (ver, por exemplo, Nye Jr. (2002b) e Keohane e Nye Jr. (2001)). Ele, no entanto, não desdenha o papel da força e a importância central da segurança. Mesmo entre os países avançados, a força pode desempenhar um importante papel político, aponta Nye Jr. Inibir ameaças e assegurar o acesso a recursos indispensáveis, como o petróleo, contribui para aumentar a influência dos Estados Unidos sobre seus aliados, os quais costumam ver com bons olhos a presença de tropas americanas responsáveis por assegurar sua proteção. É o caso da Europa ocidental, do Japão e da Coréia do Sul.

Após essas advertências, no entanto, Nye Jr. pondera a respeito dos limites impostos ao uso da força em um contexto de revolução da informação e de globalização. A ênfase sobre a força militar e a conquista reduziu significativamente e isso explicar-se-ia por quatro razões principais: $i$ ) a natureza das armas nucleares, excessivamente custosas para ser empregadas a não ser em situações extremas; $i i$ ) a ascensão do nacionalismo nas últimas décadas tornou mais difícil governar populações politicamente ativas e dispostas a rejeitar intervenções estrangeiras; iii) o crescimento do sentimento de intolerância das populações das grandes potências quanto ao número de baixas geradas pela participação de seu país nas guerras. Nesse sentido, as democracias modernas caracterizam-se pela ausência de uma "ética guerreira" e pela exigência de uma "elaborada justificação moral" por parte dos governos, com o propósito de obterem apoio popular às suas intervenções -

8 Diversos autores chamaram a atenção para esse último ponto. Ver, entre outros, Nye Jr. e Keohane (1983); Herz (1988); Kaiser (1990); Held (1991); Kennedy (1993); Villa (1999; 2001); Vieira (2001); Grugel (2002); Hermet (2002); Cohen (2003). 
mesmo naquelas circunstâncias nas quais sua sobrevivência esteja em jogo (NYE JR., 2002a, p. $32) ; i v)$ o emprego da força pode colocar em perigo as metas econômicas das principais economias do mundo. Esse perigo aplica-se, também, aos estados não democráticos que levam em consideração o impacto do uso da força para a realização de seus objetivos econômicos.

A segunda e a terceira condições são abordadas nos capítulos dois e três do livro. No capítulo dois, Joseph Nye Jr. examina a revolução da informação e trata das implicações que ela terá sobre o poder americano. Tal revolução seria positiva por ser compatível com os valores americanos, mas altera o universo da política externa norteamericana e dificulta seu controle pelos diplomatas. O raciocínio de Nye Jr. é o seguinte: o poder brando vem tornando-se mais importante do que o poder bruto. $\mathrm{O}$ avanço tecnológico na área da informação altera a natureza dos governos e da soberania, aumenta o papel dos atores não estatais na condução de diversos temas econômicos e sociais e eleva a importância do poder brando na política externa. A revolução da informação tornou a política mundial mais complexa, pois afetou as relações de poder entre os estados e favoreceu aqueles países melhor situados no desenvolvimento das tecnologias da informação. Dados apresentados pelo autor ilustram como os Estados Unidos estão situados no contexto da revolução da informação ${ }^{9}$. Para determinar o impacto da revolução da informação sobre os países, Nye Jr. considerou relevante examinar a capacidade de coletar e produzir informação nova que exige grandes investimentos. A capacidade dos americanos, da Grã-Bretanha, da França e da Rússia na alocação desses investimentos é muito superior às demais nações. A informação nova está associada ao papel dos pioneiros, responsáveis pela criação de padrões e pela arquitetura dos sistemas de informação. Nesse campo, também, os Estados Unidos estão entre os principais responsáveis pelo desenvolvimento de sistemas de informação, o que assegura sua liderança e predomínio.

\footnotetext{
9 No início do século XXI, existiriam 159 milhões de computadores no país enquanto, na América Latina toda, estimava-se algo em torno de 18 milhões. Na América do Norte 493 de cada 1000 habitantes são usuários da internet, contra oito no Oriente Médio e na África.
}

Como decorrência desse quadro, Nye Jr. afirma que o poder brando tende a ser cada vez mais decisivo e lista três condições para um país ser bem-sucedido na posse de poder brando: "(1) são aqueles cujas ideias dominantes e a cultura mais se aproximam das normas globais prevalecentes (que atualmente enfatizam o liberalismo, o pluralismo e a autonomia), (2) aqueles que mais acesso têm a múltiplos canais de comunicação e, portanto, mais influência exercem sobre a formação das questões e (3) aqueles cujo desempenho interno e internacional lhes aumenta a credibilidade" (idem, p. 123). Examinando esse conjunto de condições, o autor conclui que os Estados Unidos também seriam líderes mundiais no que diz respeito à posse de poder brando.

Ao tratar da globalização no capítulo três, Nye Jr. utiliza uma expressão capaz de resumir bem a condição americana na era da informação global. Ele afirma que a globalização é "americanização", pois os Estados Unidos conduzem a revolução da informação e dominam o conteúdo das redes de informação global criadas no país. Além disso, os Estados Unidos desempenham um papel central em todas as dimensões da globalização (militar, econômica, ambiental, social e cultural). Mas, ao mesmo tempo, estão também vulneráveis em todas essas dimensões.

Para explicar esse paradoxo, Nye Jr. afirma que a globalização seria um processo caracterizado pela formação de redes de interdependência estabelecidas entre os países, as quais variam de acordo com as distintas dimensões da globalização. Essas redes produzem efeitos sobre todos os países, inclusive os Estados Unidos. A dimensão cultural contribuiria para a compreensão mais adequada da vulnerabilidade americana e mostraria como a globalização seria uma "via de mão dupla". A cultura popular norte-americana, ao mesmo tempo em que influencia muitos países, não é bem recebida em outros. A globalização não produz homogeneidade cultural ${ }^{10}$, levando a transformação do mundo de acordo com a imagem e

\footnotetext{
10 Conforme mostrou Peter Berger (2004) no estudo organizado em conjunto com Samuel Huntington. $\mathrm{Na}$ introdução, intitulada "A dinâmica cultural da globalização", Berger mostrou que as reações à chamada "cultura global" (formada em grande medida pelos Estados Unidos) variam da aceitação à rejeição, passando pela localização (adaptação local da cultura globalizada) e pela hibridização (fusão de elementos
} 
semelhança da cultura americana. Nye Jr. observa que os imigrantes e as idéias vindas de fora são capazes de modificar essa cultura, aumentando ainda mais a atração exercida pelos Estados Unidos.

Por fim, a globalização e a revolução da informação impõem novos limites ao poder dos Estados Unidos ao alterar a própria natureza dos estados, da soberania e do papel do poder brando. O poder americano é ameaçado pela distribuição mais complexa do poder no século XXI, em que temas relevantes escapam ao controle dos estados. Essa distribuição não está relacionada à emergência de poderes nacionais capazes de desafiar os Estados Unidos, mas da emergência de novos atores e do enfraquecimento dos estados nacionais. A influência da revolução da informação e da globalização limitaria a capacidade de qualquer Estado atingir todas as metas internacionais que deseja. Todos os estados perderam parcelas de poder para atores não estatais (como empresas e Organizações Não-Governamentais), dotados de interesses próprios e orientados para a realização de seus objetivos. Ao mesmo tempo, os estados estão diante de problemas cuja solução não depende da vontade de um deles isoladamente, mas exige a cooperação entre eles, sustenta Nye Jr. - como um bom teórico do neoliberalismo nas relações internacionais. E é aí que reside o que ele chama de paradoxo do poder americano enunciado no final do primeiro capítulo do livro. Para o autor (com base na interpretação de um analista inglês), o poder americano é paradoxal, isto é, grandioso demais para ser desafiado, mas insuficiente para resolver sozinho determinados problemas da conjuntura atual, como o terrorismo global e a proliferação de armas nucleares (idem, p. 82).

Em síntese, as três análises expostas aqui de maneira sumária destacam elementos distintos do poder americano. Wallerstein situa esse poder no contexto da economia-mundo capitalista, enquanto Nye Jr. destaca a importância da dimensão cultural e ideológica do poder americano, argumentando que ela tende a ser mais decisiva no contexto da política mundial contemporânea. Pecequilo, por sua vez, procura mostrar de que forma os elementos do padrão histórico explicam as caracte-

de culturas diferentes gerando uma nova). Para uma análise desses processos, cf. Berger (idem). Estudos de caso das diferentes culturais locais e da forma como elas relacionamse com a cultura global, ver Berger e Huntington (2004). rísticas da política externa americana. Na seqüência, passo a examinar a questão específica da hegemonia na construção dessas três análises do poder americano.

\section{A HEGEMONIA E SUA APLICAÇ̃̃O NA ANÁLISE DO PODER AMERICANO}

Nas três análises, é possível identificar a aplicação do conceito de hegemonia com sentidos diferentes. Ao examinar o poder americano, Nye Jr. estabelece a separação entre poder duro (hard power) e poder brando (soft power), sendo que o poder brando contemplaria uma dimensão importante não associada à força. No seu livro, o cerne da argumentação reside justamente na caracterização e na defesa dessa dimensão, conforme foi possível observar na seção anterior. Porém, o que Nye Jr. entende por hegemonia? Ele cita Joshua Goldstein, segundo o qual hegemonia seria "a capacidade de ditar ou pelo menos dominar as regras e acertos pelos quais se conduzem as relações internacionais" (idem, p. 46). Em uma acepção mais simples, hegemonia seria a situação na qual um país tem significativamente mais recursos de poder e capacidade do que os outros. Nye Jr., em nota de rodapé na página 47 , critica os autores marxistas que tentaram construir uma teoria geral histórica sobre as transições hegemônicas. Essas tentativas teriam sido mal sucedidas em suas previsões. "A maioria tenta confinar a história em bases teóricas arbitrárias, concentrando-se em fontes particulares de poder ao mesmo tempo em que desdenham outras igualmente importantes" (idem, p. 47; nota 43). Nye Jr. prevê que a Pax Americana será duradoura em virtude do imenso e inigualável poder bruto dos Estados Unidos e de sua capacidade de adotar a contenção estratégica, isto é, tranquilizar os seus parceiros e facilitar a colaboração.

A liderança americana é pensada por Nye Jr. de maneira ampla, não se restringindo apenas à capacidade de os Estados Unidos conduzirem a ordem internacional baseada em instituições. A liderança é pensada pelo autor em conformidade com as dimensões do poder definidas por ele. Essas dimensões permitem que os Estados Unidos continuem sendo dominantes e capazes de continuar ditando as regras com o propósito de conduzir as relações internacionais. A título de exemplo, podemos mencionar a análise que ele realiza dos possíveis rivais da pax americana. Seus prováveis desafiadores seriam a China, a Rússia, 
a Índia, o Japão e a Europa. Em sua análise destes rivais, ele sustenta que a União Européia estaria mais próxima dos Estados Unidos. Os gastos militares europeus correspondem a dois terços do americano e os europeus desempenham papel central nas instituições internacionais. Para ele, a questão decisiva sobre a Europa diz respeito à sua capacidade de coesão política e cultural para agir como unidade, em um amplo espectro de questões internacionais. Dentro das instituições internacionais, como o FMI e a Organização Mundial do Comércio (OMC), a União Européia equivalese aos Estados Unidos e, se a Europa superar suas divergências internas, pode igualar-se aos americanos em poder (idem, p. 68-69) - um poder que seria mensurado pela capacidade européia de ditar regras e de conduzir os demais atores no âmbito das instituições internacionais. Em termos econômicos, os recursos de poder dos Estados Unidos são superiores aos de seus principais desafiantes, o que sugere a Nye Jr. a continuidade da liderança americana determinada pelas vantagens obtidas por esse país em termos bélicos e no âmbito da revolução da informação. Portanto, trata-se de uma liderança relacionada às dimensões do poder duro. Nesse sentido, Nye sugere uma definição de hegemonia similar à dos autores realistas: como sinônimo de dominação baseada nas capacidades bélica e econômica de um Estado.

Porém, na exposição sobre a cultura popular norte-americana como parte do poder brando é possível estabelecer aproximações entre a visão de Nye Jr. e a análise de Gramsci a respeito do papel da cultura na dominação de classe vigente nas formações sociais capitalistas. Nye Jr. aponta que existe certa ambigüidade nas relações de outros países com essa cultura. A aceitação e a rejeição fazem parte das reações à chamada cultura global formada, em grande medida, nos Estados Unidos (cf. Berger (2004) e a nota 10, acima). Nesse sentido, sua abordagem destaca a importância da cultura popular norte-americana na construção do consenso em torno da dominação dos Estados Unidos sobre os demais países. Nye Jr. adverte, no entanto, que o poder brando é mais do que simples poder cultural e não se deve exagerar o papel da cultura popular. A cultura popular é, segundo ele, um aspecto da força de atração que um Estado pode exercer sobre outros, embora essa cultura possa ser passível de rejeição em determinadas partes do mundo.
Na construção da análise de Nye Jr., é possível perceber, portanto, um dado curioso. Ao definir o significado de hegemonia, ele opta pela concepção realista e reducionista do termo ao situar a hegemonia como a situação na qual um país tem mais recursos de poder e capacidade do que os outros. No entanto, o tratamento dado ao chamado poder brando, dentro do qual ele incluiu a cultura popular norte-americana, permite aproximálo daquela inversão proposta por Gramsci dentro do pensamento marxista ao atribuir maior importância à superestrutura do que a estrutura econômica na análise das sociedades capitalistas do seu tempo. A análise do poder brando sugere que Nye Jr. vem atribuindo significativa importância à "liderança moral e intelectual" dos Estados Unidos, embora examine a liderança de maneira fragmentada ao estudá-la a partir dos outros fundamentos do poder, incluídos no rótulo de poder duro. Assim, a "liderança moral e intelectual", apesar de ser gradualmente mais importante do que as outras, não é vista pelo autor como exclusiva. Em sua análise, opta por falar em uma liderança dentro da revolução da informação, de uma liderança na globalização e de uma liderança na produção dos elementos do poder brando. É nesse sentido que considero fragmentada a discussão sobre a liderança americana no pensamento de Joseph Nye Jr.

Diferentemente de Nye Jr., Pecequilo utiliza o termo hegemonia para designar dimensões do poder americano que ela considera relevantes. A hegemonia americana permitiu aos Estados Unidos criarem a ordem internacional no período posterior à II Guerra Mundial. Essas dimensões seriam três: a estrutural, a institucional e a situacional. Pecequilo explica essas dimensões na passagem a seguir: "[...] os Estados Unidos valeram-se, para construir e sustentar sua hegemonia, de elementos variados, que vão desde os recursos concretos de poder ( $d i$ mensão estrutural) à criação de mecanismos para exercê-lo, instituições e organizações de caráter multilateral, das quais detêm a liderança (dimensão institucional), e fontes diversas, como a ideologia, as visões de mundo, os projetos e as táticas de convencimento que permitiram ampliar a sua aceitação pelos outros estados (dimensão situacional)" (PECEQUILO, 2005, p. 133; sem grifos no original).

A hegemonia americana foi fundamental para a construção da ordem pós-guerra. De acordo com J. G. Ruggie (citado por Pecequilo), os Estados Unidos teriam adotado um comportamento atípico 
na medida em que construíram uma ordem - baseada em regras e instituições - limitadora do seu próprio poder. Os Estados Unidos estiveram preocupados com a legitimidade dessa ordem e com a participação igualitária dos demais países, agindo de maneira "benevolente". Dessa forma, os americanos não teriam utilizado as assimetrias de poder existentes entre eles e seus parceiros na Europa ocidental e no Japão. Os americanos estiveram dispostos, também, a restringir essas assimetrias por meio do controle exercido pelas regras e instituições internacionais. Dessa forma, criaram condições para agregar os países aos novos mecanismos institucionais, permitindo, ainda, que tivessem representatividade e poder de decisão. Com isso, os Estados Unidos exerceram sua hegemonia a baixos custos e com menos desconfiança de seus parceiros.

A autora critica a postura daqueles que consideram a construção de uma nova ordem internacional tarefa difícil, pois não consideram um fenômeno típico das eras de transição: "a convivência entre padrões de continuidade e mudança e, principalmente, a durabilidade do caráter da ordem construída pelos Estados Unidos no pós-1945" (idem, p. 252-253). A autora sustenta que os objetivos e parâmetros da "ordem constitucional liberal democrática e aberta" criada pelos EUA no período posterior à II Guerra Mundial permanecem intactos. Mesmo precisando de modificações para adaptar-se aos novos tempos, "a tarefa norte-americana não é 'criar' uma nova ordem, mas transformar a existente para dar conta dos desafios atuais do sistema, preservando seu núcleo e inspiração" (idem, p. 254).

No que se refere à construção da ordem, Pecequilo interpreta que os Estados Unidos foram relutantes em "assumir plenamente a responsabilidade de conduzir o sistema, ao mesmo tempo em que desejava[m] garantir os canais para a plena realização de seus interesses. Ou seja, os Estados Unidos queriam os benefícios, mas não os custos da ordem, e não iriam dominá-la agressivamente, dividindo espaço e deveres com seus parceiros" (idem, p. 135). Esse comportamento seria o reflexo, também, da "natureza liberal da liderança do país, sustentada pelos princípios da natureza democrática da sociedade e da política, sempre presentes na tradição da sua política externa" (ibidem). Assim, como reflexo de elementos do padrão histórico, a hegemonia americana é exercida com o propósito de impor o poder americano de maneira benigna, conseguindo a aceitação das demais potências ao demonstrar que o propósito americano seria buscar o domínio e não a conquista, o que diminuía o potencial de contestação (ibidem).

Examinando as três dimensões do poder delimitadas por Pecequilo, é possível estabelecer aproximações entre elas e a teoria da estabilidade hegemônica. A hegemonia dos Estados Unidos é estabelecida com base nos recursos concretos de poder (a capacidade bélica, por exemplo). Com base neles, esse país constrói uma ordem internacional que lhe é favorável por meio de regras e instituições (a dimensão institucional). Os americanos exercem o papel de liderança nessa ordem construída por eles e baseada no consenso internacional. E assumem um compromisso - nada difícil - com o liberalismo, na medida em que essa ordem reflete os valores da sociedade americana que, por sua vez, geram impacto sobre o perfil do comportamento internacional da superpotência (a dimensão situacional). A ordem liberal baseada no livre-comércio é condizente com os valores básicos e fundacionais da nação americana.

A utilização do conceito de hegemonia por Pecequilo é diferente, portanto, da forma específica pela qual Wallerstein delimitou esse conceito. A hegemonia é pensada por Wallerstein no interior da sua teoria do sistema-mundo. A definição do que seria hegemonia aparece resumida na seguinte passagem: "A hegemonia no sistema interestatal refere-se à situação em que a rivalidade permanente entre as chamadas 'grandes potências' é tão desequilibrada, que uma potência é realmente primus inter pares, ou seja, uma potência pode impor suas regras e desejos [...] nas arenas econômica, política, militar, diplomática e até cultural. A base material desse poder reside na capacidade das empresas domiciliadas nessa potência atuarem de maneira mais eficiente em todos os três grandes campos econômicos - produção agrícola, comércio e finanças. Tão grande é a diferença de eficiência de que estamos falando, que essas empresas podem não apenas sobrepujar as empresas domiciliadas em outras grandes potências do mercado mundial em geral, como também, especificamente e em inúmeros casos, nos mercados internos das próprias potências rivais" (Wallerstein apud ARRIGHI \& SILVER, 2001, p. 32-33). 
Em todos os três casos na história em que foi possível identificar uma potência hegemônica (Holanda no século XVII, Grã-Bretanha no XIX e EUA no XX), a hegemonia é efeito de longos períodos de expansão competitiva que resulta em uma concentração particular de poder econômico e político. No curso da expansão competitiva, a potência hegemônica obtém sua margem decisiva de superioridade, primeiro na produção, depois, no comércio e, por fim, nas finanças. A hegemonia é conquistada logo após um período longo de guerra que resulta em um acordo, segundo Wallerstein, que visa: $(i)$ consolidar a vantagem econômica obtida pelo vencedor devido à guerra e (ii) proteger essa vantagem do desgaste. Esse acordo posterior à guerra é baseado em uma ou outra forma de liberalismo global que procura impor o princípio da livre circulação dos fatores produtivos (bens, capital e trabalho) por toda a economia mundial. "O liberalismo global atende à dupla finalidade de respaldar a dominação baseada na vantagem competitiva da potência hegemônica e 'deslegitimar os esforços das outras máquinas estatais no sentido de agir contra a superioridade econômica da nação hegemônica"” (idem, p. 33). Porém, o liberalismo global gera, também, seu próprio declínio, pois torna mais difícil à nação hegemônica adiar a disseminação da capacidade tecnológica entre nações rivais. Para manter a produção ininterrupta em uma época de máxima acumulação global, a nação hegemônica precisa elevar a renda real das camadas trabalhadoras e dos quadros dirigentes internamente. Porém, com o passar do tempo, essas duas tendências comprometem a vantagem competitiva da nação hegemônica na produção, no comércio e nas finanças. "Com isso, o sistema retorna a um novo longo período de expansão competitiva, até que um outro Estado consiga conquistar a tríplice vantagem competitiva - na produção, no comércio e nas finanças - que define a hegemonia" (idem; sem grifos no original). Wallerstein é criticado por Arrighi, Silver e outros autores por considerar, em seu modelo, que o complexo de órgãos governamentais e empresariais cumpriria um roteiro ditado por propriedades de nível sistêmico. Os autores entendem que as propriedades sistêmicas agem como forças coercitivas e ordenadoras na escolha dos estados que se tornam hegemônicos. Mas, em todos os casos, a hegemonia também implicou uma reorganização fundamental do sistema e uma mudança de suas propriedades (ARRIGHI \& SILVER, 2001, p. 35).
Arrighi e Silver derivam suas idéias de hegemonia do conceito gramsciano. A hegemonia é mais do que a dominação pura e simples e difere dela. Trata-se de um poder adicional que compete a um grupo dominante conduzir a sociedade como se estivesse servindo ao interesse geral. No contexto internacional, a liderança pode ser compreendida como a capacidade de um país conduzir o sistema internacional em uma direção desejada por ele e ser percebida como representante do interesse geral do conjunto dos estados. A liderança tomada nesse sentido aumenta o poder do Estado dominante. Arrighi e Silver adotam essa característica como definidora das hegemonias mundiais.

$\mathrm{Na}$ análise de Wallerstein, no entanto, a hegemonia é definida em um sentido mais restrito e articulado com a tríplice vantagem competitiva mencionada por ele. Essa tríplice vantagem, como se pode perceber, circunscreve-se ao status econômico alcançado pela potência hegemônica. Para o autor, compreender o poder americano no contexto atual passa, necessariamente, por uma avaliação desse status. Em outras palavras, torna-se fundamental examinar a manutenção das vantagens competitivas obtidas pelos Estados Unidos em comparação a seus rivais econômicos no sistema-mundo capitalista. Portanto, hegemonia significa o exercício de uma liderança calcada em fatores econômicos, sendo que os fatores políticos e militares são desenvolvidos em decorrência das vantagens competitivas alcançadas pela potência hegemônica.

$\mathrm{Na}$ seção anterior deste ensaio, mostramos como, para Wallerstein, a construção de instituições intergovernamentais após a II Guerra Mundial e os Acordos de Yalta estariam atrelados à criação de uma ordem estável direcionada à expansão econômica dos Estados Unidos. Essas instituições teriam um papel subordinado, isto é, sua função seria garantir a manutenção da hegemonia americana no contexto do sistema-mundo capitalista. E para entender o declínio eventual dessa hegemonia, Wallerstein concede maior importância aos fatores econômicos, mostrando, por exemplo, os riscos resultantes de investimentos excessivos na capacidade bélica do Estado americano. Esses investimentos tenderiam a enfraquecer a hegemonia americana, abrindo espaço para a sua sucessão. Nesse sentido, o autor destaca o que seria uma tendência na história de vida das potências hegemônicas. A potência dominante concen- 
tra-se no aspecto militar e o candidato a sua sucessão no aspecto econômico. Para ele, não resta dúvidas de que a hegemonia americana continuará o seu declínio e a verdadeira questão, segundo ele, é "se os Estados Unidos conseguirão encontrar uma forma de cair graciosamente, com danos mínimos para o mundo e para si próprios" (WALLERSTEIN, 2004, p. 36).

Como resultado da aplicação distinta do conceito de hegemonia, os três autores aqui examinados produziram resultados analíticos diferenciados a respeito da liderança americana. Ela foi pensada de maneira ampla e, ao mesmo tempo, fragmentada na análise de Nye Jr.: ele examina a liderança nas distintas dimensões do poder delimitadas em sua interpretação. A liderança na perspectiva de Wallerstein é situada no contexto da economia-mundo capitalista. A manutenção dessa liderança ou seu eventual declínio dependerá do status econômico da superpotência. Em Pecequilo, a liderança americana tenderia a permanecer, sobretudo porque a autora não compartilha a tese de que a ordem internacional calcada nessa liderança estaria em crise e necessitaria de uma reformulação profunda e significativa.

No entanto, em uma análise do poder, permanece sendo uma questão fundamental compreender a capacidade americana de moldar os comportamentos dos outros atores estatais por meio da análise da natureza do poder e da dimensão destacada por Gramsci: a consciência. A combinação de coerção e consciência é particularmente importante na operacionalização do termo hegemonia no campo teórico das relações internacionais. Examinar as dimensões do poder na cena internacional permitiria estabelecer separações analíticas a respeito da natureza do poder. Nas relações internacionais, não é possível apenas privilegiar a força como um instrumento de poder, já que a consciência joga um papel relevante nas relações entre os estados. $\mathrm{O}$ mesmo raciocínio pode aplicar-se, inclusive, aos estudos sobre as relações externas dos Estados Unidos no século XX. No caso do poder americano, a força militar não é a única variável explicativa importante, pois a maior parte das interpretações sobre esse poder tecem considerações a respeito da liderança dos Estados Unidos, do papel desse país na construção do consenso internacional e das instituições intergovernamentais responsáveis por estabelecer, no limite do possível, a cooperação entre os países.
Se aplicarmos essa análise às relações dos Estados Unidos com seus aliados (Europa ocidental e Japão), poderemos falar de um projeto de dominação baseado no exercício de uma liderança moldada, por sua vez, pelo consenso básico formulado pelos principais atores estatais do final da II Guerra Mundial. Em outros termos, no momento atual seria necessário examinar a continuidade desse projeto, já que não é possível discutir a superioridade dos recursos de poder (militares, econômicos, tecnológicos etc.) à disposição dos Estados Unidos. Com base nesses recursos apenas, não parece ter sentido discutir o declínio do poder americano. Mas, se falarmos em um projeto de dominação dos Estados Unidos em termos gramscianos, faz sentido discutir se está em curso o declínio ou não desse poder. Nos termos de Fiori (2007), a adesão dos dominados está em xeque, pois, nos anos 1970, era possível observar que os "sócios" (Japão e Alemanha, especialmente) passaram a duros competidores econômicos dos americanos. Outros autores chamaram a atenção para esse aspecto ao discutir o problema da legitimidade do comportamento internacional dos Estados Unidos e das intervenções militares americanas recentes. Emerson Maione de Souza (2009) apresenta as contribuições recentes de um conjunto de autores que desenvolveram estudos sobre a ordem na sociedade internacional após os atentados terroristas de 11 de setembro de 2001. Esses autores utilizaram categorias de análise formuladas pela Escola Inglesa de Relações Internacionais, de Hedley Bull, Adam Watson e Martin Wight, entre outros. Alguns desses estudos identificam uma incompatibilidade entre o comportamento dos Estados Unidos depois do 11 de setembro e as regras e instituições consideradas relevantes para os membros da sociedade internacional.

Tim Dunne (apud SOUZA, 2009) mostra que o período posterior ao 11 de setembro apresenta diferenças importantes no que se refere aos anteriores. Esse período seria diferente por duas razões: a escala de superioridade e a ideologia do excepcionalismo que guia a política externa dos EUA. Nesse momento recente, a sociedade internacional dentro de uma acepção mais densa (orientada pelo propósito de regular ou eliminar formas de guerra que ameacem a ordem internacional) estaria em xeque. Para Dunne, as principais ameaças à sociedade internacional estariam na ausência de uma balança de poder e na falta de consenso entre as potências. Dunne definiu o com- 
portamento dos Estados Unidos como uma revolta contra as principais instituições da sociedade internacional. Para esse autor, violar regras não é um problema. O problema seria desafiá-las como fazem os EUA. Segundo Bull (apud SOUZA, 2009), as disputas sobre as regras do jogo são perigosas, pois são grandes disputas sobre legitimidade. Até agora, a administração Bush quebrou normas acordadas sobre detenção e tratamento de prisioneiros (SOUZA, 2009, p. 138). A pergunta fundamental é: os membros da sociedade internacional estão dispostos a aceitar os privilégios especiais que os líderes dos EUA reclamam para $s i$ ? Se a resposta for não, a sociedade internacional está enfraquecida (idem).

Dunne enumera quatro fatores que podem contribuir para a interpretação dos EUA como hiperpotência incompatível com as regras e instituições que são consideradas vinculantes para os membros da sociedade internacional: $i$ ) a emergência de um entendimento altamente permissivo sobre o direito de autodefesa; ii) a ação preemptiva é legitimada mesmo quando nenhuma ameaça iminente foi demonstrada; iii) a hiperpotência é contra estender a outros quaisquer dessas justificativas para o uso da força; $i v$ ) os EUA continuam a ver as restrições jurídicas domésticas na ação internacional como mais importantes do que o direito internacional (idem, p. 140).

A manutenção da liderança americana é colocada em xeque pelo próprio comportamento adotado pelos EUA após o 11 de setembro. Andrew Hurrell afirma que uma "hegemonia efetiva requer a aceitação pelos outros da liderança e autoridade do hegemon" (Hurrell apud SOUZA, 2009, p. 145). Nesse sentido, os Estados Unidos colocam em xeque essa liderança ao reivindicar direitos excepcionais em relação aos demais estados. Ao mesmo tempo, comprometem essa liderança ao colocar em risco a aceitação dos liderados. Trata-se, como mostram os autores inspirados na teoria da Escola Inglesa, de um problema de legitimidade da liderança americana. Essa legitimidade é compreendida por Andrew Hurrell como o "ponto de encontro pragmático entre a efetividade política e a necessidade de um consenso moral" (idem, p. 144).

Se o problema na atualidade é discutir a liderança, o consenso possível, a legitimidade das estratégias adotadas pelos Estados Unidos e o funcionamento das instituições na ordem internacional contemporânea, o tema da hegemonia mos- tra-se relevante, pois permite examinar, de maneira articulada, esse conjunto variado de temas. Nesse sentido, o poder brando de Nye Jr., a dimensão situacional de Pecequilo e os componentes ideológicos e culturais da hegemonia americana, apenas mencionados por Wallerstein, seriam variáveis analíticas fundamentais.

\section{CONCLUSÕES}

Para concluir este ensaio, seria salutar formular uma questão substantiva para as três perspectivas aqui examinadas: quais seriam as dimensões decisivas do poder americano para se pensar a continuidade da supremacia desse poder no século XXI? Respondendo a essa questão, Immanuel Wallerstein apontaria como fator decisivo a dinâmica atual do capitalismo, em que a força militar desempenharia um papel funcional de acordo com as necessidades econômicas do desenvolvimento da economia-mundo conduzida pela hegemonia americana. No entanto, a crescente competição econômica entre os principais rivais dessa hegemonia pode colocar em xeque a supremacia do poder americano, a despeito do papel funcional do poder estatal e de seu instrumento específico, que é a força militar.

Pecequilo chama a atenção para as consequências negativas resultantes de uma política externa baseada no isolacionismo e no unilateralismo, estratégias adotadas a partir da administração Bush (2001-2009). É importante recordar que o isolacionismo e o unilateralismo fazem parte de um dos padrões históricos da política externa americana. Os dois correspondem às estratégias de inserção internacional dos Estados Unidos, em que o isolacionismo envolveria uma redução das responsabilidades desse país no sistema internacional. O unilateralismo, por sua vez, envolveria a busca pela liberdade de ação do país nesse sistema. É importante notar, também, que a construção das instituições internacionais envolveu uma ruptura com esse padrão histórico, pois os Estados Unidos optaram por assumir grandes responsabilidades na condição de potência hegemônica. É evidente que, como hegemon, desfrutavam de um grau de liberdade maior em relação a seus liderados. A opção pela guerra, adotada pelos "falcões" da administração Bush, envolveu a retomada daquele padrão histórico, produziu o desgaste da liderança americana e criou maior instabilidade internacional, sobretudo ao incentivar outros países a acelerarem seus investimentos 
militares, em especial na produção de armas de destruição em massa. Para Pecequilo, a guerra e a preparação para a guerra produziriam efeitos contrários à própria supremacia do poder americano. Para a autora, os Estados Unidos deveriam investir na preservação da ordem internacional e de sua liderança, com o propósito de atender a seus objetivos políticos e econômicos.

Para Joseph Nye Jr., a força militar não seria mais decisiva em inúmeros temas da agenda internacional americana, tendo em vista que a solução para problemas econômicos e ambientais não depende exclusivamente da vontade dos estados e do seu instrumento específico, que é a força. Para Nye Jr., o poder americano atual depende mais da sua capacidade de construir o consenso do que propriamente do uso da força. Nesse sentido, a análise de Pecequilo aproximar-se-ia da de Nye Jr., pois ambos atribuem um papel importante à manutenção do consenso, seja por meio das instituições internacionais (Pecequilo), seja por meio dos elementos do poder brando (Nye Jr.).

Em síntese, nas três perspectivas é possível notar os receios quanto aos efeitos perversos resultantes de um comportamento internacional dos Estados Unidos orientado pelo isolacionismo, a partir de 2001. Wallerstein e Pecequilo pela instabilidade internacional gerada por esse comportamento. Nye Jr., pelo investimento em dimensões do poder americano menos estratégicas na política internacional contemporânea.

Esse comportamento pode ser explicado dentro de outras perspectivas de análise. As análises amparadas na Escola Inglesa também demonstraram preocupação semelhante, conforme apontei no final da seção anterior deste ensaio. É o caso, também, de John Mearsheimer (apud FIORI, 2007 , p. 41) que justificaria o comportamento americano recente em conformidade com o que ele denominou de "tragédia das grandes potências": toda grande potência estaria obrigada a seguir expandindo seu poder mesmo em períodos de paz. Por isso, a guerra será sempre uma constante nas relações internacionais, fato comprovado pelos dados de Jack Levy (apud FIORI, 2007, p. 41). Levy estimou que as grandes potências envolveram-se em guerras durante $75 \%$ do período que vai de 1495 a 1975, iniciando uma guerra a cada sete ou oito anos. Por essa razão, Fiori tem razão ao considerar que "as principais crises do sistema foram provocadas pelo próprio poder que deveria ser o seu grande pacificador e estabilizador" (idem, p. 15).

Nesse sentido, é possível compreender os receios manifestados por Immanuel Wallerstein, Joseph Nye Jr. e Cristina Pecequilo a respeito do comportamento dos Estados Unidos a partir de 2001. Esses receios estão pautados por perspectivas de análise distintas. No entanto, o declínio do poder desse país (se de fato ocorrer em um futuro próximo) será causado, principalmente, pelas opções e estratégias adotadas pelos formuladores da sua política externa.

Por fim, a "solidão" da superpotência restante é preocupante, conforme alerta Hobsbawm (2007). Essa "solidão" pode ser tanto auto-imposta (por meio de estratégias isolacionistas de política externa, adotadas a partir da administração Bush), como pela ausência de opositores expressivos ao poder americano, sobretudo após a desintegração da URSS no início da década de 1990. Sem a principal referência norteadora de sua política externa durante os anos da Guerra Fria, os Estados Unidos buscaram novos referenciais para orientar seu comportamento internacional. Conforme aponta Pecequilo, os atentados terroristas de 11 de setembro de 2001 forneceram aos Estados Unidos um "novo inimigo", que serviu de inspiração para a elaboração da Doutrina Bush. O combate ao terrorismo transnacional contribuiu para um reposicionamento dos Estados Unidos no mundo atual por meio dos referenciais fornecidos pelos terroristas, por suas organizações desterritorializadas e pelas supostas ameaças ao "modo de vida americano", representadas, também, pelos países que integrariam o chamado "Eixo do Mal".

Sob o olhar crítico e desconfiado dos analistas e da comunidade internacional, esse reposicionamento produziu mais insegurança em diversas partes do mundo, como podemos observar na tensão recente entre as duas Coréias. A perspectiva "esquizofrênica" e "megalomaníaca" (este termo pertence a Hobsbawm (2007)) dos partidários da guerra (os "falcões") criou mais instabilidades e aumentou as tensões em um mundo caracterizado pela crescente desigualdade econômica e social que assola, sobretudo, os países “esquecidos”, especialmente na África. Por essa razão, a incansável produção sobre o poder americano e suas consequências para o sistema internacional continuará relevante por muito mais tempo. 
Alexsandro Eugenio Pereira (alexsep@uol.com.br) é Doutor em Ciência Política pela Universidade de São Paulo (USP) e Professor de Ciência Política na Universidade Federal do Paraná (UFPR).

\section{REFERÊNCIAS BIBLIOGRÁFICAS}

ARRIGHI, G. 2007. As três hegemonias do capitalismo histórico. In: GILL, S. (org.). Gramsci, materialismo histórico e relações internacionais. Rio de Janeiro: UFRJ.

ARRIGHI, G. \& SILVER, B. 2001. Caos e governabilidade no moderno sistema mundial. Rio de Janeiro: Contraponto.

BERGER, P. L. 2004. Introdução: a dinâmica cultural da globalização. In: BERGER, P. L. \& HUNTINGTON, S. P. (orgs.). Muitas globalizações. Diversidade cultural no mundo contemporâneo. Rio de Janeiro: Record.

BERGER, P. L. \& HUNTINGTON, S. P. (orgs.). 2004. Muitas globalizações. Diversidade cultural no mundo contemporâneo. Rio de Janeiro: Record.

BRAUDEL, F. 1987. A dinâmica do capitalismo. Rio de Janeiro: Rocco.

CARNOY, M. 1990. Estado e teoria política. $3^{\text {a }}$. ed. Campinas: Papirus.

COHEN, J. 2003. Sociedade civil e globalização. Repensando categorias. Dados, Rio de Janeiro, v. 46, n. 3, p. 419-459. Disponível em: http://www.scielo.br/pdf/dados/v46n3/ a01v46n3.pdf. Acesso em: 8.maio.2011.

COX, R. 2007. Gramsci, hegemonia e relações internacionais: um ensaio sobre o método. In: GILL, S. (org.). Gramsci, materialismo histórico e relações internacionais. Rio de Janeiro: UFRJ.

COX, R. \& JACOBSON, H. K. 1990. Uma primeira abordagem: a análise da tomada de decisão. In: BRAILLARD, P. Teoria das relações internacionais. Lisboa: Calouste Gulbenkian.

COX, R. 1986. Social Forces, States and World Orders: Beyond International Relations Theory. In: KEOHANE, R. (ed.). Neorealism and its Critics. New York: Columbia University.

DOUGHERTY, J. E. \& PFALTzGRAFF, R. 2003. Relações internacionais. As teorias em confronto. Lisboa: Gradiva.
FIORI, J. L. 2007. Formação, expansão e limites do poder global. In: FIORI, J. L. (org.). $O$ poder americano. $3^{\mathrm{a}}$. ed. Petrópolis: Vozes.

GARCIA, A. S. 2010. Hegemonia e imperialismo: caracterizações da ordem mundial capitalista após a II Guerra Mundial. Contexto Internacional, Rio de Janeiro, v. 32, n. 1, p. 155177, jan.-jun. Disponível em: http:// publique.rdc.puc-rio.br/contextointernacional/ media/v32n1a05.pdf. Acesso em: 8.maio.2011.

GILPIN, R. 2002. A dinâmica da economia política internacional. In:__. A economia política das relações internacionais. Brasília: UNB.

GRAMSCI, A. 1978. Obras escolhidas. São Paulo: M. Fontes.

GRIFFITHS, M. 2005. Cinqüenta grandes estrategistas das relações internacionais. São Paulo: Contexto.

GRUGEL, J. 2002. El retorno del Estado al activismo transnacional. Pensamiento Proprio, Buenos Aires, n. 16, p. 61-85, jul.-dez. Disponível em: http://www.cries.org/contenidos/ 16.pdf. Acesso em: 8.maio.2011.

HELD, D. 1991. Democracia, o Estado-nação e o sistema global. Lua Nova, São Paulo, n. 23, p. 145-194, mar. Disponível em: http:// www.scielo.br/pdf/ln/n23/a10n23.pdf. Acesso em: 8.maio.2011.

HERMET, G. 2002. A democratização dos países emergentes e as relações entre o Estado, as OIGs e as ONGs. In: MILANI, C.; ARTURI, C. \& SOLINIS, G. (orgs.). Democracia e Governança Mundial. Que regulações para o século XXI? Porto Alegre: UFRGS.

HERZ, M. 1988. A dimensão cultural das relações internacionais e os atores não-governamentais. Contexto Internacional, Rio de Janeiro, vol. 8, n. 4, p. 69-82, jul.-dez. Disponível em: http://publique.rdc.puc-rio.br/ contextointernacional/media/ Herz_vol8.ano4.pdf. Acesso em: 8.maio.2011. 
HOBWBAWM, E. 2007. Globalização, democracia e terrorismo. São Paulo: Companhia das Letras.

JERVIS, R. 2005. American Foreign Policy in a New Era. New York: Routledge.

KAISER, K. 1990. A política transnacional: para uma teoria da política multinacional. In: BRAILLARD, P. Teoria das relações internacionais. Lisboa: Calouste Gulbekian.

KENNEDY, P. 1989. Ascensão e queda das grandes potências. Transformações econômicas e conflito militar de 1500 a 2000. $3^{\text {a }}$. ed. Rio de Janeiro: Campus.

1993. Preparando para o século XXI. Rio de Janeiro: Campus.

KEOHANE, R. O. 2005. After Hegemony. Cooperation and Discord in the World Political Economy. Princeton: Princeton University.

KEOHANE, R. O. \& NYE JR., J. 1998. Power and Interdependence in the Information Age. Foreign Affairs, Buffalo, v. 77, n. 5, Sep.-Oct. Disponível em: http://ics.leeds.ac.uk/papers/ pmt/exhibits/534/power.pdf . Acesso em: 8.maio.2011

2001. Power and Interdependence: World Politics in Transition. New York: Longman.

LACERDA, G. B. 2004. A ação externa dos Estados Unidos em perspectiva. Revista Brasileira de Ciências Sociais, São Paulo, v. 19, n. 54, p. 169-174, fev. Disponível em: http:// www.scielo.br/pdf/rbcsoc/v19n 54/ a12v1954.pdf. Acesso em: 8.maio.2011.

LÊNIN, I. I. 1990. Os princípios do socialismo e a guerra de 1914-1915. In: BRAILLARD, P. Teoria das relações internacionais. Lisboa: Calouste Gulbekian.

MASCHIETTO, R. H. 2003. Resenha de "A política externa dos Estados Unidos", de Cristina Soreanu Pecequilo. Revista Brasileira de Política Internacional, Brasília, v. 46, n. 2, p. 195-198, jul.-dez. Disponível em: http:// redalyc.uaemex.mx/pdf/358/35846214.pdf. Acesso em: 8.maio.2011.
NYE JR., J. 2002a. O paradoxo do poder americano. Por que a única superpotência do mundo não pode prosseguir isolada. São Paulo: UNESP.

2002b. Compreender os conflitos internacionais. Lisboa: Gradiva.

NYE JR., J. \& KEOHANE, R. 1983. Transnational Relations and World Politics. Cambridge (MA): Harvard University.

PECEQUILO, C. S. 2005. A política externa dos Estados Unidos. 2a ${ }^{\mathrm{a}}$. ed. Porto Alegre: UFRGS.

SOUZA, E. M. 2009. Ordem e justiça na sociedade internacional pós-11 de setembro. Revista Brasileira de Politica Internacional, Brasília, v. 52, n. 11, p. 133-149, jan.-jun. Disponível em: http://www.scielo.br/pdf/rbpi/v52n1/ v52n1a07.pdf. Acesso em: 8.maio.2011.

TILLY, C. 1996. Coerção, capital e estados europeus. São Paulo: USP.

VEIRA, L. 2001. Os argonautas da cidadania. A sociedade civil na globalização. Rio de Janeiro: Record.

VILLA, R. D. 1999. Da crise do realismo à segurança global multidimensional. São Paulo: Annablume.

2001. A construção de um sistema internacional policêntrico: atores estatais e não-estatais societais no pós-guerra fria. Cena Internacional, Brasília, v. 3, n. 2, p. 65-87.

VIZENTINI, P. G. F. 1997. O Sistema de Yalta como condicionante da política internacional do Brasil e dos países do terceiro mundo. Revista Brasileira de Política Internacional, Brasília, v. 40, n. 1, p. 5-17, jan.-jun. Disponível em: http://www.scielo.br/pdf/rbpi/v40n1/ v40n1a01.pdf. Acesso em: 8.maio.2011.

VIZENTINI, P. G. F. \& WIESEBRON, M. (orgs.). 2006. Neohegemonia americana ou multipolaridade? Polos de poder e sistema internacional. Porto Alegre: UFRGS.

WALLERSTEIN, I. 2001. Capitalismo histórico e civilização capitalista. Rio de Janeiro: Contraponto.

2004. O declínio do poder americano. Rio de Janeiro: Contraponto. 